\title{
Fused bicyclic piperidines and dihydropyridines by dearomatising cyclisation of the enolates of nicotinyl-substituted esters and ketones
}

\author{
Heloise Brice, Jonathan Clayden* and Stuart D. Hamilton
}

\section{Full Research Paper}

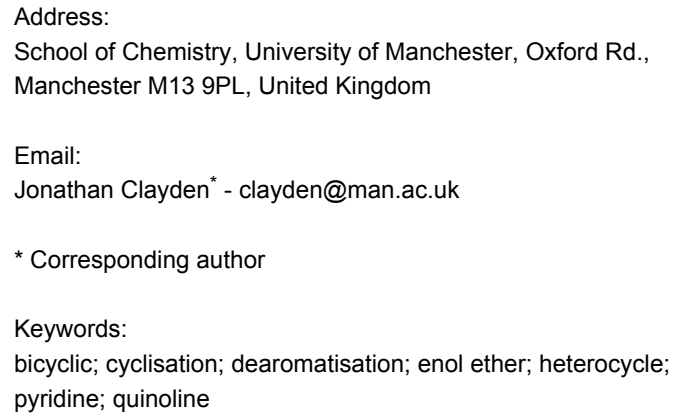

Beilstein Journal of Organic Chemistry 2010, 6, No. 22. doi:10.3762/bjoc.6.22

Received: 05 January 2010

Accepted: 11 February 2010

Published: 02 March 2010

Associate Editor: J. Murphy

(C) 2010 Brice et al; licensee Beilstein-Institut.

License and terms: see end of document.

\begin{abstract}
The silyl enol ether derivatives of ketones or esters tethered by a hydrocarbon or ether linkage to the 3-position of a pyridine ring undergo dearomatising nucleophilic attack on the ring once it is activated (as an acylpyridinium species) by the addition of methyl chloroformate. The bicyclic dihydropyridine products are in some cases unstable, but may be isolated after hydrogenation as fused bicyclic piperidines.
\end{abstract}

\section{Introduction}

Oxidative [1-3] or reductive (nucleophilic) [4-21] dearomatising cyclisation reactions are effective strategies for rapidly building complexity and new reactivity from simple, readily made starting materials. We have used cyclisations of benzamide-stabilised carbanions, for example, to give bicyclic functionalised indolinones as intermediates in the synthesis of the neuroactive amino acids [22-32], while related cyclisations of pyridyl-, nicotinamide- and isonicotinamide-containing carbanions yield related bicyclic dihydropyridines [33,34].

While reactive carbanions derived from allyl or benzyllithiums will undergo dearomatising addition even into relatively electron rich rings [35-38], the scope of the dearomatisation can be extended to much less reactive nucleophiles with a more electron deficient aromatic acceptor [39-41]. Thus enolates of glycine esters 1 carrying isonicotinoyl or nicotinoyl N-substituents cyclise readily to yield bicyclic amino acid derivatives 2 (Scheme 1a for example) [39]. Even greater reactivity towards intramolecular nucleophilic attack is exhibited by isonicotinamides when activated by $\mathrm{N}$-sulfonation [40,41]. For example, the $\mathrm{N}$-furylmethyl isonicotinamide $\mathbf{3}$ cyclises to the doubly dearomatised bis-spirocycle 4 on treatment with triflic anhydride in the presence of an alcohol [41] (Scheme 1b).

In this paper we report the results of cyclising the enolates of ester and ketones tethered to a nicotinyl nucleus via chains 
<smiles>[R]N(CC(=O)OC(C)(C)C)C(=O)c1cccnc1</smiles>
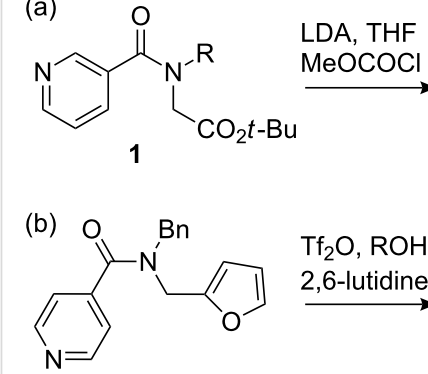

3

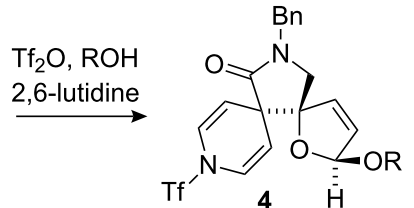

$4 \quad \overline{\mathrm{H}}$
Scheme 1: Dearomatising cyclisations (a) of enolates; (b) of electronrich heteroaromatics.

which do not incorporate an amide linkage. The starting materials for these cyclisations do not benefit from the favourable conformational disposition of amides $\mathbf{1}$ and $\mathbf{3}$, making the reactions more challenging. Likewise, the products are evidently less stable than those produced by the reactions in Scheme 1a, but nonetheless they allow new, partially saturated "drug-like" heterocyclic systems to be formed.

\section{Results and Discussion}

\section{Formation of a carbocyclic ring by dearomat- ising cyclisation}

The study was initiated with the synthesis of the $\delta$-nicotinyl ketone 7 as illustrated in Scheme 2. Ethyl benzoylacetate was alkylated with 3-(3-iodopropyl)pyridine 5 and the product 6 hydrolysed and decarboxylated to yield the pyridine 7 in moderate yield.<smiles>ICCCc1cccnc1</smiles><smiles>CCOC(=O)CC(=O)c1ccccc1</smiles><smiles>[R]OC(=O)C(CCCc1cccnc1)C(=O)c1ccccc1</smiles>
acetone, $16 \mathrm{~h}$

$\mathrm{NaOH}, \mathrm{EtOH}$,<smiles>O=C(CCCCc1cccnc1)c1ccccc1</smiles>

Scheme 2: Synthesis of ketone 7.

On treatment of 7 with LDA in THF at $-78{ }^{\circ} \mathrm{C}$, followed by trapping with methyl chloroformate, a yield of $40 \%$ of the bicyclic hexahydroisoquinoline 8 was obtained (Scheme 3), which even after extensive experimentation could not be improved. Lack of crystallinity and overlapping ${ }^{1} \mathrm{H}$ NMR signals prevented us from confirming the relative stereochemistry, and the assignment shown in Scheme 3 is on the basis that the benzoyl group of $\mathbf{8}$ is likely to lie on the exo face of the azadecalin system.

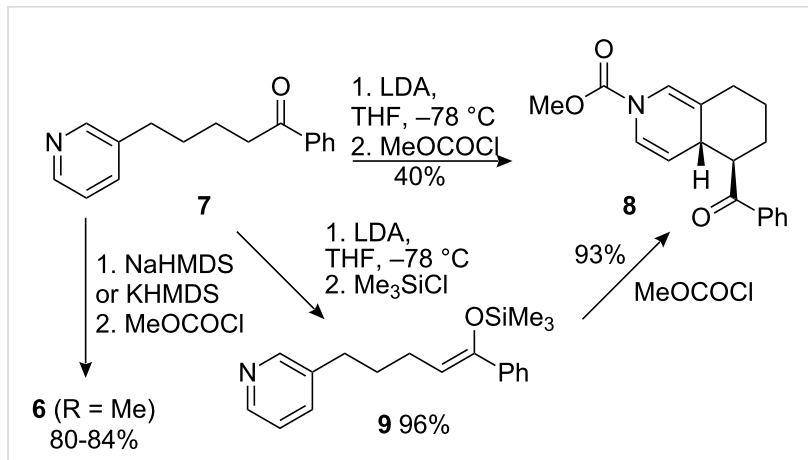

Scheme 3: Dearomatising cyclisation to a 5-benzoylhexahydroisoquinoline.

We assume, in line with previous results [39], that cyclisation occurs only after the addition of the electrophilic trap (which, precedent suggests, attacks the pyridine lone pair and activates the ring as an acylpyridinium species even in the presence of the lithium enolate). Attempts to use bases with a sodium or potassium counter ion led instead to a high yield of the Claisen product $6(\mathrm{R}=\mathrm{Me})$, presumably because the sodium and potassium enolates are more reactive than the lithium enolate and compete too well with $\mathrm{N}$-acylation.

We surmised that effective cyclisation onto the acylpyridinium species, avoiding the $\mathrm{N}$ - vs. C-acylation problem, might be made possible by decreasing the reactivity of the enolate still further, transforming it into a silyl enol ether 9. Silyl enol ethers and ketene acetals are known to add effectively to pyridinium species in an intermolecular manner [42-46]. Thus 7 was converted to silyl enol ether 9 in excellent yield under standard conditions. A single geometrical isomer was obtained, presumably $Z$ as shown. On treatment with methyl chloroformate, enol ether $\mathbf{9}$ cyclised to yield $\mathbf{8}$ again as a single diastereoisomer but in a greatly improved yield of $93 \%$. The strategy of using a less nucleophilic specific enolate equivalent is clearly an effective way of improving selectivity, allowing the chloroformate to activate the pyridine without competing attack by the enolate.

Next we extended the reaction to the cyclisation of a $\delta$-nicotinyl butyrate ester 12 encouraged by the observations of Onaka [47], who demonstrated that silyl ketene acetals can be added (in an intermolecular fashion) to electron deficient pyridines in the presence of trimethylsilyl triflate, tetrabutylammonium fluoride or a montmorillonite clay.

The cyclisation precursor was synthesised by using the procedure of Hayashi [48] employing a Horner-WadsworthEmmons olefination between nicotinaldehyde and phosphonate 10. The resulting mixture of dienes $\mathbf{1 1}$ gave ester $\mathbf{1 2}$ after hydrogenation (Scheme 4). 
<smiles>CCOC(=O)CCCCc1cccnc1</smiles>

Scheme 4: Synthesis of ester 12.

It proved challenging to isolate cleanly the silyl ketene acetal derived from 12, so instead we decided to form and cyclise the silyl derivative in a single pot. Thus, ester 12 was added to LDA at $-78{ }^{\circ} \mathrm{C}$, and the enolate quenched with trimethylsilyl chloride. After 15 min methyl chloroformate was added and the solution warmed to room temperature. Complete consumption of starting material (by TLC) was accompanied by the appearance of a single less polar spot $\left(R_{\mathrm{f}} 0.77\right.$; EtOAc-petroleum ether 1:1). ${ }^{1} \mathrm{H}$ NMR analysis of the crude product after rapid work-up showed two significant sets of new signals at 6.55-6.80 ppm $(2 \mathrm{H})$ and $4.65-5.10 \mathrm{ppm}(1 \mathrm{H})$ consistent with the dihydropyridine protons of the expected dearomatised product $\mathbf{1 4}$ (Scheme 5). However, in contrast with the clean spectra and dearomatised product 8 derived from ketone 7, duplication of many of the signals in the crude ${ }^{1} \mathrm{H}$ NMR spectrum of $\mathbf{1 4}$ suggested the existence of either a mixture of diastereoisomers or rotamers caused by restricted rotation of the carbamate group.

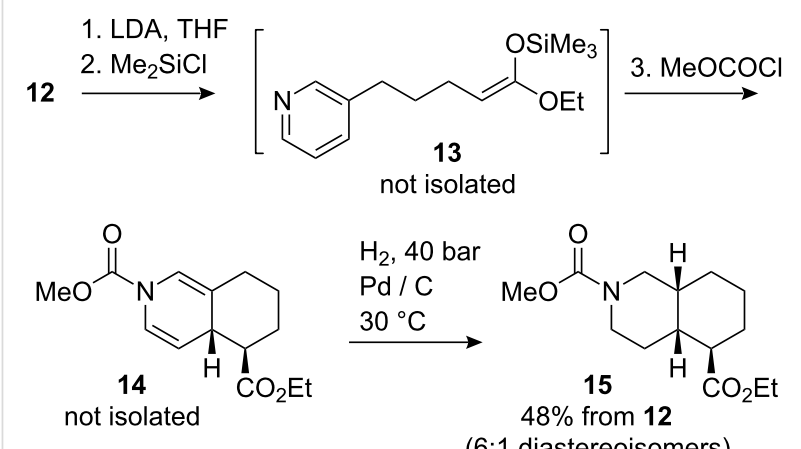

Scheme 5: Dearomatising cyclisation of ester 12.

No dihydropyridine was isolable from this mixture by flash chromatography, probably due to rapid re-aromatisation. However, immediate hydrogenation at ambient pressure using the conditions developed by Arnott for related 3,4-fused dihydropyridines [39] gave $\mathbf{1 5}$ in $45 \%$ yield after chromatography as an inseparable mixture of two diastereoisomers in a ratio of approximately $6: 1$. A slightly improved yield of $48 \%$ was obtained by the use of an H-cube flow hydrogenation apparatus at 40 bar and $30{ }^{\circ} \mathrm{C}$.

Unfortunately, again the lack of crystallinity and the large number of overlapping signals in the ${ }^{1} \mathrm{H}$ NMR spectrum frustrated an unequivocal assignment of the stereochemistry. However, hydrogenation of related fused dihydropyridines has always led to cis stereochemistry at the ring junction [32,39]. The consequent expected axial-equatorial relationship between the protons at the ring junction is supported by a coupling constant of $4.2 \mathrm{~Hz}$ between these protons in $\mathbf{1 5}$ (Figure 1) in the major product diastereoisomer. The corresponding $12.9 \mathrm{~Hz}$ coupling to the proton $\alpha$ to the ester group is consistent with adoption of an exo-equatorial orientation by this substituent.

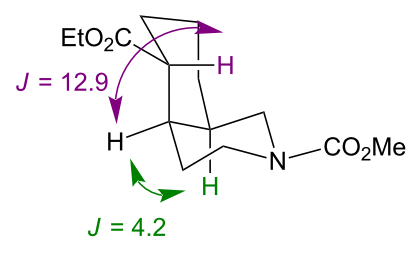

Figure 1: Coupling constants $(\mathrm{Hz})$ in the major diastereoisomer of 15.

\section{Formation of a tetrahydrofuran by dearomat- ising cyclisation}

Encouraged by the successful formation of carbocyclic rings in dearomatising cyclisations of nicotinyl ketones and esters, we moved to extend the reaction to the analogous formation of tetrahydofuranyl esters by cyclisation of starting materials incorporating an enolate nucleophile and a nicotinyl electrophile tethered through an ether linkage. Alkylation of 3-hydroxymethylpyridine by $t$-butyl bromoacetate $\mathbf{1 7}$ a or bromopropionate 17b suffered from competing $\mathrm{N}$-alkylation but returned acceptable yields of the esters 18a and 18b (Scheme 6). As with 13, we anticipated that the silyl ketene acetal derivatives 19

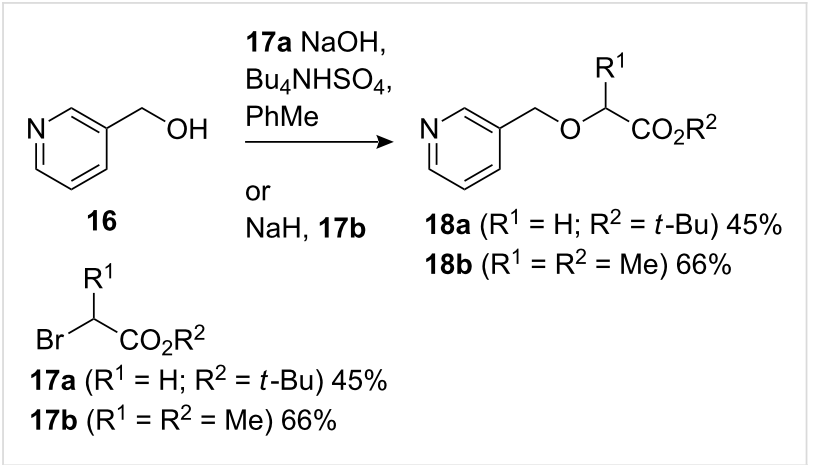

Scheme 6: Synthesis of esters 18 
would be challenging to isolate, so both starting esters $18 \mathbf{a}$ and 18b were treated with LDA and $\mathrm{Me}_{3} \mathrm{SiCl}$ followed by methyl chloroformate (Scheme 7). As with 14, re-aromatisation was fast and the crude products $\mathbf{1 9}$ were therefore hydrogenated at atmospheric pressure to give $\mathbf{2 0 a}$ in up to $32 \%$ yield from $\mathbf{1 8 a}$ and $\mathbf{2 0 b}$ in up to $35 \%$ yield from $\mathbf{1 8 b}$. The instability of the two non-isolable intermediates meant however that these yields were not consistently reproducible and yields around $25 \%$ were more commonly observed. However, scrupulous avoidance of contact with oxygen before the hydrogenation step improved the yield of 20a to $41 \%$. Attempted cyclisation without formation of the silyl enol ether (i.e. omitting $\mathrm{Me}_{3} \mathrm{SiCl}$ ) led to a complex mixture of products.
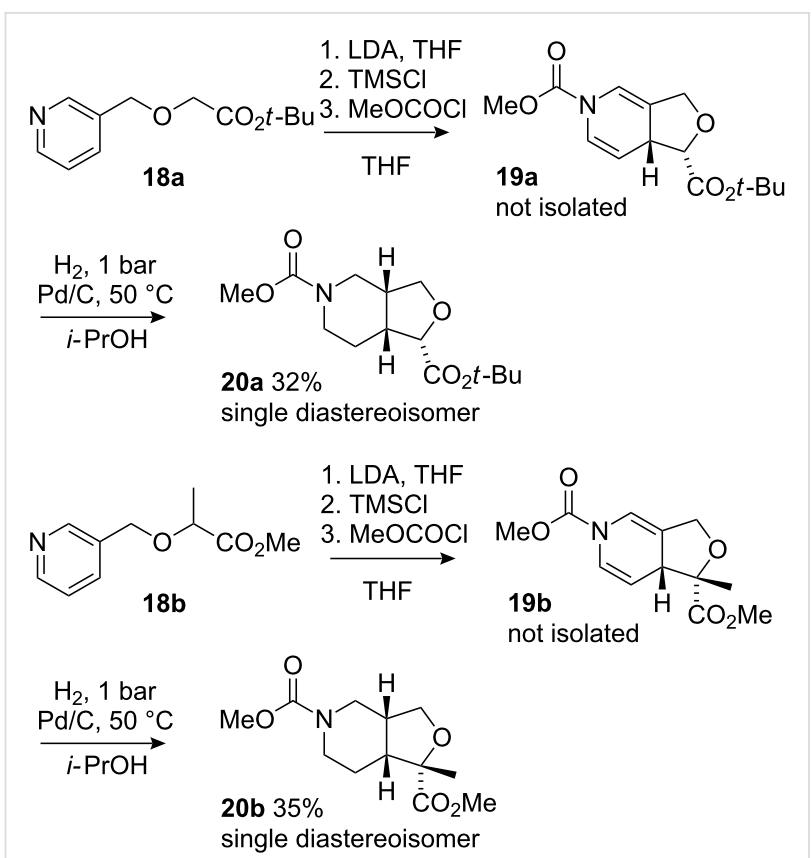

Scheme 7: Dearomatising cyclisation to form tetrahydrofurans.

In both cases the cyclic products were obtained as single diastereoisomers, indicating a diastereoselective cyclisation and a face-selective hydrogenation. An nOe experiment on cyclic ether $\mathbf{2 0 b}$, irradiating the $7 \mathrm{a}$ ring junction proton, showed nOe enhancements of protons 3a, $6(1 \mathrm{H})$ and $7(1 \mathrm{H})$ (Figure 2). This result is consistent with a cis-fused ring junction. A lack of conclusive nOes prevented determination of the stereochemistry at the ester-bearing centres of 20 a or $20 \mathbf{b}$. However, a similar cyclisation with an amide tether [39] had resulted in an endo-orientated ester substituent, and the stereochemistries of $\mathbf{2 0}$ are accordingly shown with the ester orientated endo.

\section{Conclusion}

Tethered ketone or ester enolate nucleophiles undergo dearomatising attack on a pyridine ring to yield bicyclic products.

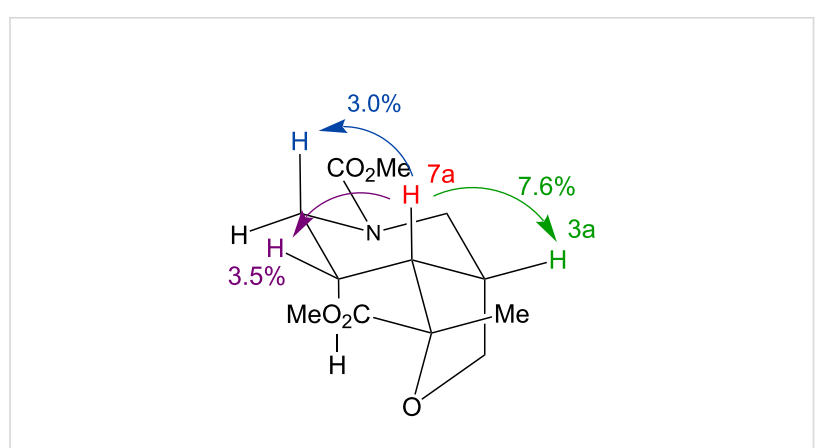

Figure 2: Determination of the stereochemistry of 20b. Arrows indicate nuclear Overhauser enhancements.

Yields are greatest if the enolate is first stabilised as a silyl enol ether, presumably because acylation of the pyridine ring to give the electrophilic acylpyridinium species is cleaner. The bicyclic dihydropyridine products are unstable towards re-aromatisation, but can be isolated in moderate to excellent yield if they are hydrogenated in situ, especially when oxygen is excluded prior to and during the hydrogenation.

\section{Experimental}

\section{5-Benzoyl-5,6,7,8-tetrahydro-4aH-isoquino- line-2-carboxylic acid methyl ester (8)}

Methyl chloroformate $(0.056 \mathrm{ml}, 0.722 \mathrm{mmol})$ was added to a solution of 9 (45 mg, $0.144 \mathrm{mmol})$ and triethylamine $(0.02 \mathrm{ml}$, $0.144 \mathrm{mmol})$ in dichloromethane $(5 \mathrm{ml})$ at $-78{ }^{\circ} \mathrm{C}$. After warming to room temperature, dichloromethane was added (30 $\mathrm{ml})$, and the solution washed with water $(3 \times 10 \mathrm{ml})$ and brine $(10 \mathrm{ml})$. The combined aqueous layers were extracted with dichloromethane $(10 \mathrm{ml})$ and the combined organic layers dried $\left(\mathrm{Na}_{2} \mathrm{SO}_{4}\right)$, filtered and concentrated under reduced pressure to furnish a light yellow oil. The oil was purified by flash column chromatography $\left(\mathrm{SiO}_{2}\right.$; petroleum ether-EtOAc 9:1) to yield the title compound as a colourless oil $(40 \mathrm{mg}, 0.135 \mathrm{mmol}$, 93\%); silica gel TLC $R_{\mathrm{f}} 0.38$ (petroleum ether-EtOAc 4:1); IR (thin film) $v_{\max }\left(\mathrm{cm}^{-1}\right): 1721$ (carbamate $\mathrm{C}=\mathrm{O}$ ), 1677 (ketone $\mathrm{C}=\mathrm{O}) ;{ }^{1} \mathrm{H}$ NMR $\left(500 \mathrm{MHz}, \mathrm{CDCl}_{3}, \delta_{\mathrm{H}}\right): 7.80(2 \mathrm{H}, \mathrm{d}, J=7.5$ $\mathrm{Hz}, \mathrm{Ph}-\mathrm{H}), 7.41(1 \mathrm{H}, \mathrm{t}, J=8.0 \mathrm{~Hz}, \mathrm{Ph}-\mathrm{H}), 7.32(2 \mathrm{H}, \mathrm{t}, J=8.0$ $\mathrm{Hz}, \mathrm{Ph}-\mathrm{H}), 6.67$ (1H, br, py-H $)_{2}, 6.54(1 \mathrm{H}, \mathrm{br}, \mathrm{py}-\mathrm{H} 6), 4.60$ $\left(2 \mathrm{H}, \mathrm{br}, \mathrm{py}-\mathrm{H}_{5}\right) 3.64\left(3 \mathrm{H}, \mathrm{br}, \mathrm{OCH}_{3}\right), 3.33\left(2 \mathrm{H}, \mathrm{m}, \mathrm{py}-\mathrm{H}_{4}\right.$ and $\mathrm{CH}), 2.1-1.3\left(6 \mathrm{H}\right.$, br-m, $\left.\mathrm{CH}_{2}\right) ;{ }^{13} \mathrm{C}$ NMR (125 MHz, $\mathrm{CDCl}_{3}$, $\left.\delta_{\mathrm{C}}\right): 202.9$ (ketone $\left.\mathrm{C}=\mathrm{O}\right), 152.2($ carbamate $\mathrm{C}=\mathrm{O}), 137.3$, 133.6, 129.1 and 128.8 (aromatic), 123.4 and 123.0 (py- $\mathrm{C}_{6}$ ), 120.9 and 119.9 (py- $\mathrm{C}_{3}$ ), 117.1 and 116.8 (py- $\left.\mathrm{C}_{2}\right), 108.1$ and 107.7 (py$\left.\mathrm{C}_{5}\right), 60.8\left(\mathrm{py}-\mathrm{C}_{4}\right), 53.8$ and $53.7\left(\mathrm{OCH}_{3}\right), 38.0$ and $37.8(\mathrm{CH})$, 32.5 and $32.4\left(\mathrm{CH}_{2}\right), 31.7$ and $31.6\left(\mathrm{CH}_{2}\right), 27.5\left(\mathrm{CH}_{2}\right)$; CIMS $\mathrm{m} / \mathrm{z}$ (relative intensity): $298\left(100 \%, \mathrm{M}+\mathrm{H}^{+}\right), 238(40 \%$, $\mathrm{M}-\mathrm{CO}_{2} \mathrm{Me}$ ); EIMS $\mathrm{m} / \mathrm{z}$ (relative intensity): $297\left(10 \%, \mathrm{M}^{+}\right)$. [Found: $\mathrm{M}+\mathrm{H}^{+}$, 298.1436. $\mathrm{C}_{18} \mathrm{H}_{20} \mathrm{NO}_{3}$ requires 298.1438]. 
5-Ethyl 2-methyl octahydroisoquinoline-2,5(1H) dicarboxylate (15)

$n$-Butyllithium $(0.36 \mathrm{~mL}$ of a $1.8 \mathrm{M}$ solution in hexane) was added to a solution of diisopropylamine $(0.11 \mathrm{~mL}, 0.75 \mathrm{mmol})$ in THF $(15 \mathrm{~mL})$ at $0{ }^{\circ} \mathrm{C}$ and the mixture stirred for $15 \mathrm{~min}$ before cooling to $-78{ }^{\circ} \mathrm{C}$. A solution of ester $12(0.104 \mathrm{~g}, 0.5$ $\mathrm{mmol})$ in THF $(5 \mathrm{~mL})$ and then trimethylsilyl chloride $(0.10$ $\mathrm{mL}, 0.75 \mathrm{mmol}$ ) were added using a cannula. The solution was stirred at $-78^{\circ} \mathrm{C}$ for $15 \mathrm{~min}$, methyl chloroformate $(0.19 \mathrm{~mL}$, $2.5 \mathrm{mmol}$ ) was added and the solution warmed to room temperature. The solution was rapidly added to a saturated sodium hydrogen carbonate solution $(30 \mathrm{~mL})$, extracted with EtOAc (2 $\times 30 \mathrm{~mL}$ ), dried $\left(\mathrm{MgSO}_{4}\right)$, and concentrated to yield an oil. The crude oil was dissolved in isopropanol $(6 \mathrm{~mL})$, and $10 \%$ palladium/carbon ( $0.053 \mathrm{~g}, 0.05 \mathrm{mmol})$ was added and the suspension immediately placed under a hydrogen atmosphere. The suspension was warmed to $60{ }^{\circ} \mathrm{C}$ for $50 \mathrm{~h}$, filtered through celite and evaporated under reduced pressure. The residue was purified by flash chromatography $\left(\mathrm{SiO}_{2}\right.$; EtOAc-petroleum ether $1: 19$ to $1: 1)$ to yield the title compound $(0.061 \mathrm{~g}, 45 \%)$ as a yellow oil which was approximately a $6: 1$ mixture of diastereoisomers; $R_{\mathrm{f}}($ EtOAc-petroleum ether 1:1) 0.45; IR (film) $v_{\max }\left(\mathrm{cm}^{-1}\right): 1730(\mathrm{C}=\mathrm{O}$ ester $), 1702(\mathrm{C}=\mathrm{O}$ carbamate $) ;{ }^{1} \mathrm{H}$ NMR (300 MHz, $\left.\mathrm{CDCl}_{3}, \delta_{\mathrm{H}}\right): 3.95-4.25(2 \mathrm{H}, \mathrm{m}, 1-\mathrm{H}$ and/or $3-\mathrm{H}), 4.13\left(2 \mathrm{H}, \mathrm{q}, J=7.5 \mathrm{~Hz}, \mathrm{CH}_{2} \mathrm{CH}_{3}\right), 3.68\left(3 \mathrm{H}, \mathrm{s}, \mathrm{OMe}_{\mathrm{maj}}\right)$, $3.65\left(\mathrm{OMe}_{\min }\right), 2.85-3.00(1 \mathrm{H}$, br m, $1-\mathrm{H}$ or $3-\mathrm{H}), 2.63-2.76$ $(1 \mathrm{H}, \mathrm{br}, \mathrm{m}, 1-\mathrm{H}$ or $3-\mathrm{H}), 2.49(1 \mathrm{H}, \mathrm{dt}, J=13.0 \mathrm{~Hz}, 4.0,5-\mathrm{H})$, $2.24(1 \mathrm{H}$, ap dq, $J=13.0 \mathrm{~Hz}, 4.0, \mathrm{CH}), 1.83(1 \mathrm{H}, \mathrm{dt}, J=12.5$ $\mathrm{Hz}, 3.0, \mathrm{CH}), 1.65-1.74\left(3 \mathrm{H}, \mathrm{m}, \mathrm{CH}_{2}\right), 1.57(1 \mathrm{H}, \mathrm{dd}, J=13.0$ $\left.\mathrm{Hz}, 3.5, \mathrm{CH}_{2}\right), 1.37-1.51\left(2 \mathrm{H}, \mathrm{m}, \mathrm{CH}_{2}\right), 1.17-1.35(3 \mathrm{H}, \mathrm{m}$, $\left.\mathrm{CH}_{2}\right), 1.25\left(3 \mathrm{H}, \mathrm{t}, J=7.5 \mathrm{~Hz}, \mathrm{CH}_{2} \mathrm{CH}_{3}\right) ;{ }^{13} \mathrm{C} \mathrm{NMR}\left(\mathrm{CDCl}_{3}\right.$, $\left.\delta_{\mathrm{C}}\right): 174.6(\mathrm{C}=\mathrm{O}), 156.7(\mathrm{C}=\mathrm{O}), 60.5\left(\mathrm{OCH}_{2}\right), 52.8(\mathrm{OMe}), 49.9$ $\left(\mathrm{CH}_{2}\right), 47.0(\mathrm{COCH}), 44.4\left(\mathrm{NCH}_{2}\right), 40.8(\mathrm{CH}), 37.1(\mathrm{CH}), 37.1$ $\left(\mathrm{CH}_{\min }\right), 30.0\left(\mathrm{CH}_{2}\right), 25.2\left(\mathrm{CH}_{2}\right), 24.5\left(\mathrm{CH}_{2 \mathrm{~min}}\right), 24.0\left(\mathrm{CH}_{2}\right)$, $22.1\left(\mathrm{CH}_{2}\right), 21.5\left(\mathrm{CH}_{2 \mathrm{~min}}\right), 14.6\left(\mathrm{CH}_{2} \mathrm{CH}_{3}\right) ; \mathrm{MS} m / z$ (relative intensity): $270\left(100 \%, \mathrm{MH}^{+}\right)$; (Found: $\mathrm{MH}^{+}, 270.1699$. $\mathrm{C}_{14} \mathrm{H}_{24} \mathrm{NO}_{4}$ requires $\left.\mathrm{MH}^{+}, 270.1700\right)$.

\section{1-tert-Butyl 5-methyl hexahydrofuro[3,4- c]pyridine-1,5(3H)-dicarboxylate (20a)}

$n$-Butyllithium $(0.34 \mathrm{~mL}$ of a $1.9 \mathrm{M}$ solution in hexane) was added to a solution of diisopropylamine $(0.11 \mathrm{~mL}, 0.75 \mathrm{mmol})$ in THF $(10 \mathrm{~mL})$ at $0{ }^{\circ} \mathrm{C}$ and stirred for $15 \mathrm{~min}$ before cooling to $-78{ }^{\circ} \mathrm{C}$. A solution of the ester $18 \mathrm{a}(0.112 \mathrm{~g}, 0.5 \mathrm{mmol})$ in THF $(5 \mathrm{~mL})$ was added using a cannula followed by trimethylsilyl chloride $(0.10 \mathrm{~mL}, 0.75 \mathrm{mmol})$. The solution was then stirred at $-78{ }^{\circ} \mathrm{C}$ for $45 \mathrm{~min}$, methyl chloroformate $(0.19 \mathrm{~mL}, 2.5 \mathrm{mmol})$ was added and the solution warmed to room temperature. The solution was rapidly worked-up under a nitrogen atmosphere by addition to saturated sodium hydrogen carbonate solution (30 $\mathrm{mL})$ and extraction with EtOAc $(15 \mathrm{~mL}) .10 \%$ Palladium on charcoal $(0.053 \mathrm{~g}, 0.05 \mathrm{mmol})$ was added and the suspension immediately placed under a hydrogen atmosphere. The suspension was warmed to $45^{\circ} \mathrm{C}$ for $18 \mathrm{~h}$, filtered through Celite and evaporated under reduced pressure. The residue was purified by flash chromatography $\left(\mathrm{SiO}_{2}\right.$; EtOAc-petroleum ether 1:4 to $1: 1)$ to yield the title compound $(0.058 \mathrm{~g}, 41 \%)$ as white prisms; m.p. $49-51{ }^{\circ} \mathrm{C}$ (from $\left.\mathrm{Et}_{2} \mathrm{O}\right) ; R_{\mathrm{f}}($ EtOAc-petroleum ether $1: 1)$ 0.23; IR (film) $v_{\max }\left(\mathrm{cm}^{-1}\right): 1745(\mathrm{C}=\mathrm{O}$ ester $), 1705(\mathrm{C}=\mathrm{O}$ carbamate; ${ }^{1} \mathrm{H}$ NMR $\left(300 \mathrm{MHz}, \mathrm{CDCl}_{3}, \delta_{\mathrm{H}}\right): 4.37(1 \mathrm{H}, \mathrm{d}, J=$ $5.0 \mathrm{~Hz}, 1-\mathrm{H}), 3.95-4.10(2 \mathrm{H}, \mathrm{m}, 4-\mathrm{H}(1 \mathrm{H})$ and 6-H $(1 \mathrm{H})), 3.98$ $\left(1 \mathrm{H}, \mathrm{t}, J=8.5 \mathrm{~Hz}, \mathrm{OCH}_{\mathrm{a}} \mathrm{H}_{\mathrm{b}}\right), 3.79\left(1 \mathrm{H}, \mathrm{t}, J=8.5 \mathrm{~Hz}, \mathrm{OCH}_{\mathrm{a}} H_{\mathrm{b}}\right)$, $3.67(3 \mathrm{H}, \mathrm{s}, \mathrm{OMe}), 3.14-3.28(1 \mathrm{H}, \mathrm{m}, 4-\mathrm{H}), 2.71-2.87(1 \mathrm{H}, \mathrm{m}$, 6-H), 2.44-2.57 (2H, m, 3a-H and 7a-H), 1.50-1.58 (2H, m, 7-H), $1.47\left(9 \mathrm{H}, \mathrm{s},\left(\mathrm{CH}_{3}\right)_{3}\right) ;{ }^{13} \mathrm{C} \mathrm{NMR}\left(\mathrm{CDCl}_{3}, \delta_{\mathrm{C}}\right): 169.9$ $(\mathrm{C}=\mathrm{O}), 156.2(\mathrm{C}=\mathrm{O}), 82.1\left(\mathrm{C}\left(\mathrm{CH}_{3}\right)_{3}\right), 81.3(1-\mathrm{C}), 69.2(3-\mathrm{C})$, 52.9 (OMe), 42.6 (6-C), 41.7 (4-C), 39.6 (7a-C), 38.3 (3a-C), $28.4\left(\left(\mathrm{CH}_{3}\right)_{3}\right), 22.2(7-\mathrm{C}) ; \mathrm{MS} m / z$ (relative intensity): 286 $\left(15 \%, \mathrm{MH}^{+}\right), 230\left(100 \%, \mathrm{MH}^{+}-\mathrm{C}\left(\mathrm{CH}_{3}\right)_{3}\right)$; (Found: $\mathrm{MH}^{+}$, 286.1646. $\mathrm{C}_{14} \mathrm{H}_{23} \mathrm{NO}_{5}$ requires $\left.\mathrm{MH}^{+}, 286.1649\right)$.

\section{Dimethyl 1-methylhexahydrofuro[3,4- c]pyridine-1,5(3H)-dicarboxylate (20b)}

$n$-Butyllithium ( $0.34 \mathrm{~mL}$ of a $1.9 \mathrm{M}$ solution in hexane) was added to a solution of diisopropylamine $(0.11 \mathrm{~mL}, 0.75 \mathrm{mmol})$ in THF $(15 \mathrm{~mL})$ at $0{ }^{\circ} \mathrm{C}$ and stirred for $20 \mathrm{~min}$ before cooling to $-78^{\circ} \mathrm{C}$. A solution of the ester $\mathbf{1 8 b}(0.098 \mathrm{~g}, 0.5 \mathrm{mmol})$ in THF $(5 \mathrm{~mL})$ was added using a cannula followed by trimethylsilyl chloride $(0.10 \mathrm{~mL}, 0.75 \mathrm{mmol})$. The solution was then stirred at $-78{ }^{\circ} \mathrm{C}$ for $15 \mathrm{~min}$ and methyl chloroformate $(0.19 \mathrm{~mL}, 2.5$ $\mathrm{mmol}$ ) was added and the solution warmed to room temperature. The solution was rapidly worked-up by addition of saturated sodium hydrogen carbonate solution $(30 \mathrm{~mL})$, extracted with EtOAc $(2 \times 30 \mathrm{~mL})$, dried $\left(\mathrm{MgSO}_{4}\right)$ and evaporated under reduced pressure. The residue was dissolved in propan-2-ol (7 $\mathrm{mL}), 10 \%$ palladium on charcoal $(0.053 \mathrm{~g}, 0.05 \mathrm{mmol})$ was added and the suspension was immediately placed under a hydrogen atmosphere. The suspension was warmed to $50{ }^{\circ} \mathrm{C}$ for $24 \mathrm{~h}$, filtered through celite, washed with EtOAc $(5 \times 10 \mathrm{~mL})$ and evaporated under reduced pressure. The residue was purified by flash chromatography $\left(\mathrm{SiO}_{2}\right.$; EtOAc-petroleum ether $3: 17$ to $1: 1)$ to yield the title compound $(0.033 \mathrm{~g}, 35 \%)$ as a colourless oil; $R_{\mathrm{f}}$ (EtOAc-petroleum ether 1:1) 0.25; IR (film) $v_{\max }\left(\mathrm{cm}^{-1}\right): 1752(\mathrm{C}=\mathrm{O}$ ester $), 1702(\mathrm{C}=\mathrm{O}$ carbamate $) ;{ }^{1} \mathrm{H}$ NMR $\left(300 \mathrm{MHz}, \mathrm{CDCl}_{3}, \delta_{\mathrm{H}}\right): 4.07(1 \mathrm{H}, \mathrm{t}, J=8.5 \mathrm{~Hz}$, $\left.\mathrm{OCH}_{\mathrm{a}} \mathrm{H}_{\mathrm{b}}\right), 3.81\left(1 \mathrm{H}, \mathrm{t}, J=9.0 \mathrm{~Hz}, \mathrm{OCH}_{\mathrm{a}} H_{\mathrm{b}}\right), 3.75-4.02(2 \mathrm{H}, \mathrm{m}$, 4- $\mathrm{H}$ and 6-H), $3.75(3 \mathrm{H}, \mathrm{s}, \mathrm{OMe}), 3.24(1 \mathrm{H}, \mathrm{br} \mathrm{d}, J=12.5 \mathrm{~Hz}$, $4-\mathrm{H}$ or $6-\mathrm{H}), 2.79(1 \mathrm{H}, \mathrm{t}, J=12.0 \mathrm{~Hz}, 4-\mathrm{H}$ or $6-\mathrm{H}), 2.66(1 \mathrm{H}, \mathrm{br}$ s, 3a-H), 2.17-2.27 (1H, m, 7a-H), 1.49-1.64 (2H, m, 7-H), $1.46\left(3 \mathrm{H}, \mathrm{s},\left(\mathrm{CH}_{3}\right) ;{ }^{13} \mathrm{C} \mathrm{NMR}\left(\mathrm{CDCl}_{3}, \delta_{\mathrm{C}}\right): 174.0(\mathrm{C}=\mathrm{O}\right.$ ester $)$, $156.4(\mathrm{C}=\mathrm{O}$ carbamate), 87.5 (1-C), 69.1 (3-C), 53.0 (OMe), 52.4 (OMe), 45.1 (7a-C), 42.6 (6-C), 41.8 (4-C), 36.9 (3a-C), 
$25.1\left(\mathrm{CCH}_{3}\right), 23.6$ (7-C); $\mathrm{MS} \mathrm{m} / z$ (relative intensity): 258 $\left(100 \%, \mathrm{MH}^{+}\right), 275\left(55 \%, \mathrm{MNH}_{4}^{+}\right)$; (Found: $\mathrm{MH}^{+}, 258.1340$. $\mathrm{C}_{12} \mathrm{H}_{19} \mathrm{NO}_{5}$ requires $\left.\mathrm{MH}^{+}, 258.1336\right)$.

\section{Supporting Information}

\section{Supporting Information File 1}

Synthesis and characterisation data of starting materials [http://www.beilstein-journals.org/bjoc/content/ supplementary/1860-5397-6-22-S1.pdf]

\section{Acknowledgements}

We are grateful to the EPSRC, GlaxoSmithKline (HB) and AstraZeneca (SH) for studentships, and to Drs Emma Blaney and Rukhsana Mohammed for valuable discussions.

\section{References}

1. Zhdankin, V. V.; Stang, P. J. Chem. Rev. 2008, 108, 5299. doi:10.1021/cr800332c

2. Vo, N. T.; Pace, R. D. M.; O'Hara, F.; Gaunt, M. J. J. Am. Chem. Soc. 2008, 130, 404. doi:10.1021/ja077457u And references therein.

3. Hamamoto, H.; Anilkumar, G.; Hirofumi, T.; Kita, Y. Chem.-Eur. J. 2002, 8, 5377. doi:10.1002/1521-3765(20021202)8:23<5377::AID-CHEM5377>3.0.C $\mathrm{O} ; 2-\mathrm{H}$

4. Dai, M.; Danishefsky, S. J. Heterocycles 2009, 77, 157. doi:10.3987/COM-08-S(F)6

5. López-Ortiz, F.; Iglesias, M. J.; Fernández, I.; Andujar Sanchez, C. M.; Ruiz-Gómez, G. Chem. Rev. 2007, 107, 1580. doi:10.1021/cr030207। (see for review).

6. Wang, Z.; Xi, Z. Synlett 2006, 1275. doi:10.1055/s-2006-939083

7. Nevárez, Z.; Woerpel, K. A. J. Org. Chem. 2008, 73, 8113. doi:10.1021/jo801502x

8. Liu, L.; Wang, Z.; Zhao, F.; Xi, Z. J. Org. Chem. 2007, 72, 3484. doi:10.1021/jo070160u

9. Ruiz-Gómez, G.; Iglesias, M. J.; Serrano-Ruiz, M.; García-Granda, S.; Francesch, A.; López-Ortiz, F.; Cuevas, C. J. Org. Chem. 2007, 72, 3790. doi:10.1021/jo070276q

10. Ruiz-Gómez, G.; Francesch, A.; Iglesias, M. J.; López-Ortiz, F.; Cuevas, C.; Serrano-Ruiz, M. Org. Lett. 2008, 10, 3981. doi:10.1021/ol801463g

11. Kumaran, R. S.; Brüdgam, I.; Reissig, H.-U. Synlett 2008, 991. doi:10.1055/s-2008-1072512

12. Ovens, C.; Martin, N. G.; Procter, D. J. Org. Lett. 2008, 10, 1441. doi:10.1021/ol8002095

13. Clayden, J.; Kenworthy, M. N.; Helliwell, M. Org. Lett. 2003, 5, 831. doi:10.1021/ol0340585

14. Clayden, J.; Kenworthy, M. N. Org. Lett. 2002, 4, 787. doi:10.1021/ol0172626

15. Clayden, J.; Menet, C. J.; Mansfield, D. J. Org. Lett. 2000, 2, 4229. doi:10.1021/ol006786n

16. Clayden, J.; Tchabanenko, K.; Yasin, S. A.; Turnbull, M. D. Synlett 2001, 302. doi:10.1055/s-2001-10772
17. Ahmed, A.; Clayden, J.; Yasin, S. A. Chem. Commun. 1999, 231. doi:10.1039/a808218i

18. Ahmed, A.; Clayden, J.; Rowley, M. Chem. Commun. 1998, 297. doi:10.1039/a707683e

19. Ahmed, A.; Clayden, J.; Rowley, M. Synlett 1999, 1954. doi:10.1055/s-1999-2977

20. Bragg, R. A.; Clayden, J. Tetrahedron Lett. 1999, 40, 8323. doi:10.1016/S0040-4039(99)01765-7

21. Clayden, J.; Purewal, S.; Helliwell, M.; Mantell, S. J. Angew. Chem., Int. Ed. 2002, 41, 1049. doi:10.1002/1521-3773(20020315)41:6<1049::AID-ANIE1049>3.0.CO; 2-7

22. Clayden, J. Total synthesis of kainoids by dearomatizing anionic cyclisation. In Strategies and Tactics in Organic Synthesis; Harmata, M., Ed.; Academic Press, 2004; Vol. 4, pp 72-96. doi:10.1016/S1874-6004(04)80008-X

23. Clayden, J.; Knowles, F. E.; Baldwin, I. R. J. Am. Chem. Soc. 2005, 127, 2412. doi:10.1021/ja042415g

24. Clayden, J.; Knowles, F. E.; Menet, C. J. Tetrahedron Lett. 2003, 44, 3397. doi:10.1016/S0040-4039(03)00570-7

25. Clayden, J.; Knowles, F. E.; Menet, C. J. Synlett 2003, 1701. doi:10.1055/s-2003-40993

26. Clayden, J.; Menet, C. J.; Tchabanenko, K. Tetrahedron 2002, 58, 4727. doi:10.1016/S0040-4020(02)00379-4

27. Clayden, J.; Tchabanenko, K. Chem. Commun. 2000, 317. doi:10.1039/a909325g

28. Ahmed, A.; Bragg, R. A.; Clayden, J.; Tchabanenko, K. Tetrahedron Lett. 2001, 42, 3407. doi:10.1016/S0040-4039(01)00501-9

29. Bragg, R. A.; Clayden, J.; Bladon, M.; Ichihara, O. Tetrahedron Lett. 2001, 42, 3411. doi:10.1016/S0040-4039(01)00502-0

30. Clayden, J.; Menet, C. J.; Mansfield, D. J. Chem. Commun. 2002, 38. doi:10.1039/b109188c

31. Clayden, J.; Kenworthy, M. N. Synthesis 2004, 1721. doi:10.1055/s-2004-829138

32. Clayden, J.; Read, B.; Hebditch, K. R. Tetrahedron 2005, 61, 5713 doi:10.1016/j.tet.2005.04.003

33. Clayden, J.; Hamilton, S. D.; Mohammed, R. T. Org. Lett. 2005, 7, 3673. doi:10.1021/ol051214u

34. Clayden, J.; Hennecke, U. Org. Lett. 2008, 10, 3567. doi:10.1021/ol801332n

35. Clayden, J.; Turnbull, R.; Pinto, I. Org. Lett. 2004, 6, 609. doi:10.1021/ol0364071

36. Clayden, J.; Turnbull, R.; Helliwell, M.; Pinto, I. Chem. Commun. 2004, 2430. doi:10.1039/b409150g

37. Clayden, J.; Farnaby, W.; Grainger, D. M.; Hennecke, U.; Mancinelli, M.; Tetlow, D. J.; Hillier, I. H.; Vincent, M. A. J. Am. Chem. Soc. 2009, 131, 3410. doi:10.1021/ja808959e

38. Clayden, J.; Dufour, J.; Grainger, D.; Helliwell, M. J. Am. Chem. Soc. 2007, 129, 7488. doi:10.1021/ja071523a

39. Arnott, G.; Clayden, J.; Hamilton, S. D. Org. Lett. 2006, 8, 5325. doi:10.1021/ol062126s

40. Arnott, G.; Brice, H.; Clayden, J.; Blaney, E. Org. Lett. 2008, 10, 3089. doi:10.1021/ol801092s

41. Brice, H.; Clayden, J. Chem. Commun. 2009, 1964. doi:10.1039/b901558b

42. Raussou, S.; Gosmini, R.; Mangeney, P.; Alexakis, A.; Commerçon, M. Tetrahedron Lett. 1994, 35, 5433. doi:10.1016/S0040-4039(00)73518-0

43. Yamada, S.; Morita, C. J. Am. Chem. Soc. 2002, 124, 8184. doi:10.1021/ja0203317 
44. Rudler, H.; Denise, B.; Xu, Y.; Parlier, A.; Vaissermann, J.

Eur. J. Org. Chem. 2005, 3724. doi:10.1002/ejoc.200500162

45. Bosch, J.; Bennasar, M.-L. Synlett 1995, 587. doi:10.1055/s-1995-5007

46. Rudler, H.; Parlier, A.; Sandoval-Chavez, C.; Herson, P.; Daran, J.-C.

Angew. Chem., Int. Ed. 2008, 47, 6843. doi:10.1002/anie.200801879

47. Onaka, M.; Ohno, R.; Izumi, Y. Tetrahedron Lett. 1989, 30, 747.

doi:10.1016/S0040-4039(01)80299-9

48. Tanouchi, T.; Kawamura, M.; Ohyama, I.; Kajiwara, I.; Iguchi, Y.;

Okada, T.; Miyamoto, T.; Taniguchi, K.; Hayashi, M. J. Med. Chem.

1981, 24, 1149. doi:10.1021/jm00142a006

\section{License and Terms}

This is an Open Access article under the terms of the Creative Commons Attribution License

(http://creativecommons.org/licenses/by/2.0), which permits unrestricted use, distribution, and reproduction in any medium, provided the original work is properly cited.

The license is subject to the Beilstein Journal of Organic

Chemistry terms and conditions:

(http://www.beilstein-journals.org/bjoc)

The definitive version of this article is the electronic one which can be found at: doi:10.3762/bjoc. 6.22 